\title{
Comunicação
}

[Communication]

\section{Comparação entre métodos de estocagem de DNA extraído de amostras de sangue, sêmen e pêlos e entre técnicas de extração}

\author{
[Comparison between storage methods of DNA extracted from blood, semen and hair and between \\ the techniques of extraction] \\ E.G.A. Coelho, D.A.A. Oliveira, C.S Teixeira, I.B.M. Sampaio, S.G. Rodrigues, C. Alves \\ Escola de Veterinária da UFMG - Laboratório de Genética \\ Caixa Postal 567 \\ 30161-970 - Belo Horizonte, MG
}

\begin{abstract}
A biologia molecular tem criado ferramentas para pesquisa, tanto na medicina humana como na medicina veterinária. A reação em cadeia da polimerase (PCR) possibilita testes altamente sensíveis, cujas aplicações vão desde o diagnóstico clínico até a programas de melhoramento animal. Contudo, tais procedimentos dependem da habilidade de se extrair DNA em quantidade suficiente e de um extrato de boa qualidade. Há vários métodos de purificação do DNA genômico, no entanto, ainda persistem problemas como contaminação por DNA estranho, inibidores de PCR e sensibilidade da molécula de DNA, que facilitam sua quebra. Também o método de estocagem do DNA extraído pode promover a degradação do material obtido. Este trabalho teve como objetivo avaliar diferentes métodos de extração de DNA para sangue, sêmen e pêlos, bem como analisar a qualidade e a quantidade do extrato obtido e os métodos de estocagem, de modo a determinar os procedimentos ideais de manipulação do DNA para cada tipo de tecido a ser trabalhado na rotina de laboratório.
\end{abstract}

Amostras de sangue, sêmen e pêlos foram colhidas de seis touros de diferentes raças zebuínas, mantidos em uma central de inseminação artificial. Elas foram divididas em duas alíquotas e submetidas a duas diferentes técnicas de extração de DNA. Após a extração, cada alíquota foi novamente dividida em duas e armazenadas em freezer $\left(-20^{\circ} \mathrm{C}\right)$ e geladeira $\left(4^{\circ} \mathrm{C}\right)$ para análises periódicas da quantidade e qualidade dos extratos obtidos.

Para o exame do DNA extraído de linfócitos colheram-se, por venopunção, $10 \mathrm{ml}$ de sangue em tubos a vácuo estéreis, os quais foram mantidos resfriados a $4^{\circ} \mathrm{C}$ até o momento da extração. Para a extração do DNA de pêlos utilizaram-se bulbos capilares e para a extração de sêmen, paletas contendo esse material diluído em conservante com gema de ovo. Fez-se a extração de DNA utilizando-se duas técnicas por tecido (técnica da proteinase $\mathrm{K}$ ou técnica permanente e técnica do $\mathrm{NaOH}$ ou técnica rápida). $\mathrm{Na}$ extração do DNA do sangue pela técnica permanente usou-se a metodologia

Recebido para publicação em 29 de maio de 2003

Recebido para publicação, após modificações, em 11 de setembro de 2003

E-mail: denise@vet.ufmg.br 
descrita por Lewis e Stewart-Haynes (1992). As extrações de DNA do sêmen (duas técnicas) e do sangue pela técnica rápida foram feitas segundo protocolos do Stormont Laboratories Inc. Woodland CA-EUA (uso sob licença). Para extração do DNA dos pêlos nas duas técnicas, os protocolos empregados foram fornecidos pelo Laboratório de Genética Veterinária da Universidade da Califórnia-Davis (uso sob licença). As amostras foram quantificadas em espectrofotômetro (Shimadzu - modelo UV$160^{\mathrm{A}}$ ), utilizando-se comprimentos de ondas de 260nm e 280nm (Sambrook et al., 1989; Crain, 1990; Gallagher, 1994; Leff et al., 1995; Cattaneo et al., 1997). Amplificações periódicas (de três em três meses) das amostras de DNA extraído foram feitas usando-se o primer RM 29, o qual mostrou-se eficiente para bovinos em estudos prévios realizados por Barendse et al.
(1994). As amostras amplificadas foram diluídas em tampão de corrida $2 \mathrm{x}$ e formamida $50 \%$. A seguir foram submetidas a eletroforese em gel PAGE (8\%) em cubas verticais (Hoefer modelo SE 280). Empregou-se o método de coloração por nitrato de prata. Após a coloração, os géis foram fotografados para avaliação dos padrões de amplificação do DNA extraído. Em intervalos de três meses, num total de nove meses, foram feitas quantificações do DNA. Fez-se a análise estatística utilizando-se o delineamento em parcelas subsubdivididas segundo Sampaio (1998).

A partir das leituras em espectrofotômetro, foram feitas comparações entre médias da quantidade de DNA segundo a técnica de extração nos diferentes tecidos, armazenados em freezer e geladeira (Tab. 1).

Tabela 1. Médias da quantidade de DNA $(\mu \mathrm{g} / \mathrm{ml})$ segundo a técnica de extração, tecido usado, local de armazenamento e período para análise após a extração do DNA

\begin{tabular}{|c|c|c|c|c|c|c|c|c|c|c|c|c|}
\hline \multirow{3}{*}{$\begin{array}{l}\text { Tecido } \\
\text { Técnica } \\
\text { Conservação } \\
\end{array}$} & \multicolumn{4}{|c|}{ Sangue } & \multicolumn{4}{|c|}{ Sêmen } & \multicolumn{4}{|c|}{ Pêlos } \\
\hline & \multicolumn{2}{|c|}{ Rápida } & \multicolumn{2}{|c|}{ Permanente } & \multicolumn{2}{|c|}{ Rápida } & \multicolumn{2}{|c|}{ Permanente } & \multicolumn{2}{|c|}{ Rápida } & \multicolumn{2}{|c|}{ Permanente } \\
\hline & $\mathrm{F}$ & $\mathrm{G}$ & $\mathrm{F}$ & $\mathrm{G}$ & $\mathrm{F}$ & G & $\mathrm{F}$ & $\mathrm{G}$ & $\mathrm{F}$ & $\mathrm{G}$ & $\mathrm{F}$ & $\mathrm{G}$ \\
\hline $\begin{array}{l}1^{\mathrm{a}} \text { análise } \\
(3 \text { meses após a } \\
\text { extração do DNA) }\end{array}$ & 363,33 & 298,75 & 654,17 & 828,75 & 170,00 & 161,25 & 316,25 & 337,08 & 582,50 & 525,42 & 428,33 & 295,42 \\
\hline $\begin{array}{l}2^{\mathrm{a}} \text { análise } \\
(6 \text { meses após a } \\
\text { extração do DNA) }\end{array}$ & 273,33 & 264,58 & 471,67 & 645,00 & 115,83 & 201,67 & 206,25 & 440,83 & 500,42 & 561,25 & 330,42 & 361,67 \\
\hline $\begin{array}{l}3^{\mathrm{a}} \text { análise } \\
(9 \text { meses após a } \\
\text { extração do DNA) }\end{array}$ & 280,00 & 379,17 & 587,92 & 619,17 & 103,25 & 105,42 & 96,67 & 142,92 & 495,00 & 476,67 & 309,58 & 306,67 \\
\hline $\begin{array}{l}\mathrm{F}=\text { Freezer; } \mathrm{G}=\mathrm{Ge} \\
\text { As comparações } \mathrm{d} \\
\text { para comparar méd } \\
\text { técnica e tecido; } \mathrm{d} \\
\text { mesmo tecido ou }\end{array}$ & $\begin{array}{l}\text { deira. } \\
\text { médias } \\
\text { s entre t } \\
3=193 \\
\text { tecidos } \\
\text { a }=37^{\circ}\end{array}$ & 32 erente & $\begin{array}{l}\text { zadas } \\
\text { nálise } \\
\text { compa }\end{array}$ & lizand & e três & cnicas & mínim & $\begin{array}{l}\text { signifi } \\
\text { Ir méc } \\
\text { o mes }\end{array}$ & $\begin{array}{l}\text { vas }(\mathrm{dn} \\
\text { entre fr } \\
\text { ambien }\end{array}$ & $\begin{array}{l}\text { ), send } \\
\text { ezer e g } \\
\text { (freeze }\end{array}$ & $\begin{array}{l}\text { dms } 1= \\
\text { adeira, } n \\
\text { ou gelac }\end{array}$ & $\begin{array}{l}=155,726 \\
\text { ha mesma } \\
\text { deira), no }\end{array}$ \\
\hline
\end{tabular}

Não houve diferença significativa entre as médias da quantidade de DNA, nos três períodos de análises, nos três tecidos usados e nos dois métodos de conservação. Também não houve diferença entre as médias dos dois métodos de conservação no mesmo tecido e na mesma técnica de extração. Para o mesmo tecido, houve diferença entre as técnicas de extração no sangue, conservado tanto em freezer quanto em geladeira. A técnica permanente forneceu maior quantidade de DNA. Isso pode ser explicado pelo fato de na técnica permanente a extração ser feita preferencialmente em linfócitos (colhidos com pipeta Pasteur após centrifugação do sangue), enquanto que na técnica rápida utiliza-se sangue total, portanto, maior quantidade de hemácias (células anucleadas).

As médias obtidas para a quantidade de contaminação no DNA, fornecidas pela comparação com o nível de DNA puro que é dado pela relação $260 / 280 \mathrm{~nm}$ na leitura feita pelo espectrofotômetro, são mostradas na Tab. 2. O 
valor 1,8 representa um DNA livre de contaminação, e abaixo dessa estimativa considera-se que há contaminação por proteínas (Sambrook et. al., 1989).

Não houve diferença no nível de contaminação do DNA ao longo dos períodos de análises. A técnica que demonstrou menor índice de contaminação do DNA foi a permanente para sangue, confirmando a eficiência da proteinase $\mathrm{K}$ (Moore, 1993). Os maiores índices de contaminação do DNA foram observados nas extrações de DNA de sêmen, e provavelmente correspondem às proteínas da gema de ovo, utilizadas na preservação desse material. Tais achados mostraram a necessidade de adaptação das técnicas para a utilização de sêmen preservado em gema de ovo. Ajustes na diluição da amostra de sêmen, nas quantidades das soluções de lise e neutralizante, bem como no tempo de incubação da amostra, forneceram resultados satisfatórios.

Quanto aos padrões de amplificação, todas as técnicas de extração de DNA mostraram bons resultados em todos períodos de análises. Houve amplificação dos extratos, não sendo observadas diferenças entre as formas de conservação, como mostrado na Fig. 1 (A,B,C e D)

Tabela 2. Médias do nível de contaminação por proteína $(\mathrm{mg} / \mathrm{ml})$ do DNA segundo a técnica de extração, tecido usado, local de armazenamento e período para análise após a extração do DNA

\begin{tabular}{|c|c|c|c|c|c|c|c|c|c|c|c|c|}
\hline \multirow{3}{*}{$\begin{array}{l}\text { Tecido } \\
\text { Técnica } \\
\text { Conservação } \\
\end{array}$} & \multicolumn{4}{|c|}{ Sangue } & \multicolumn{4}{|c|}{ Sêmen } & \multicolumn{4}{|c|}{ Pêlos } \\
\hline & \multicolumn{2}{|c|}{ Rápida } & \multicolumn{2}{|c|}{ Permanente } & \multicolumn{2}{|c|}{ Rápida } & \multicolumn{2}{|c|}{ Permanente } & \multicolumn{2}{|c|}{ Rápida } & \multicolumn{2}{|c|}{ Permanente } \\
\hline & $\mathrm{F}$ & G & $\mathrm{F}$ & $\mathrm{G}$ & $\mathrm{F}$ & $\mathrm{G}$ & $\mathrm{F}$ & $\mathrm{G}$ & $\mathrm{F}$ & G & $\mathrm{F}$ & G \\
\hline $\begin{array}{l}1^{\mathrm{a}} \text { análise } \\
\text { ( } 3 \text { meses após a } \\
\text { extração do DNA) }\end{array}$ & 1,2393 & 1,2936 & 1,4462 & 1,4785 & 0,9033 & 0,8770 & 0,8290 & 0,7585 & 1,3059 & 1,3877 & 1,4203 & 1,3689 \\
\hline $\begin{array}{l}2^{\mathrm{a}} \text { análise } \\
\text { (6 meses após a } \\
\text { extração do DNA) }\end{array}$ & 1,0858 & 1,112 & 1,3690 & 1,3761 & 0,9195 & 0,8464 & 0,6565 & 0,6033 & 1,2741 & 1,2560 & 1,2037 & 1,2246 \\
\hline $\begin{array}{l}3^{\mathrm{a}} \text { análise } \\
(9 \text { meses após a } \\
\text { extração do DNA) }\end{array}$ & 1,1174 & 1,1550 & 1,5173 & 1,5153 & 0,7861 & 0,8488 & 0,6190 & 0,7385 & 1,1819 & 1,2027 & 1,1191 & 1,1489 \\
\hline
\end{tabular}
extração do DNA

Conservação $\mathrm{F}=$ Freezer; $\mathrm{G}=$ Geladeira.

As comparações das médias foram realizadas utilizando três diferenças mínimas significativas (dms), sendo: dms $1=0,0832$ para comparar médias entre tempos de análise (coluna); dms 2=0,0995 para comparar médias entre freezer e geladeira, na mesma técnica e tecido; dms 3=0,1104 para comparar médias entre técnicas de extração no mesmo ambiente (freezer ou geladeira), no mesmo tecido ou em tecidos diferentes.

Coeficiente de Variação $(\mathrm{CV})=6,5 \%$.

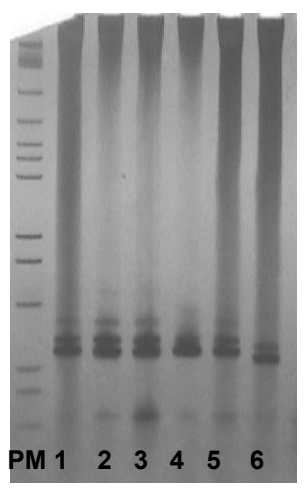

A

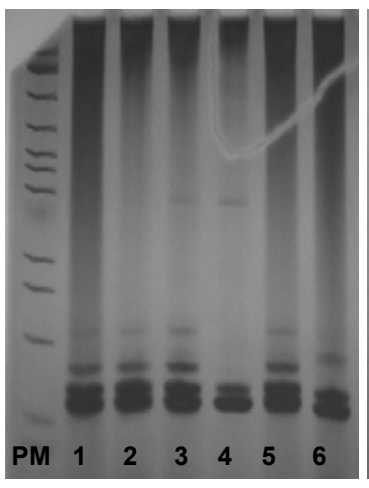

B

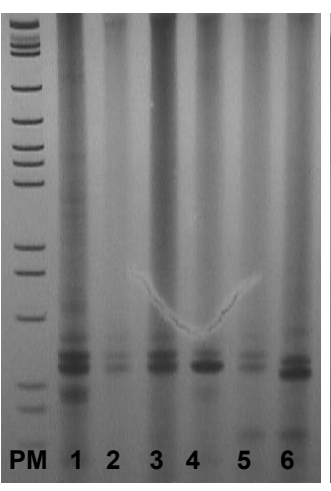

C

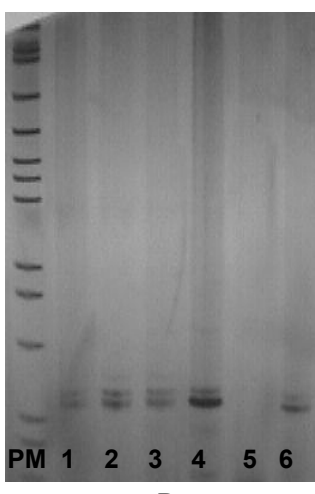

D

Figura 1. Amplificações com o primer RM 29, primeira análise (3 meses após a extração), DNA conservado em freezer. A - Técnica permanente de extração de DNA para sangue. B - Técnica rápida de extração de DNA para sangue. C - Técnica permanente de extração de DNA para pêlos. D - Técnica rápida de extração de DNA para pêlos - padrão de peso molecular com amostras dos touros (PM). 
Como já mencionado, devido ao nível de contaminantes protéicos provenientes da gema de ovo usada como preservativo, só se obteve um bom padrão de amplificação para o DNA extraído de sêmen após modificações nas técnicas (Fig. 2). Desse modo, conseguiu-se obter maior quantidade de DNA genômico bovino e boa amplificação.

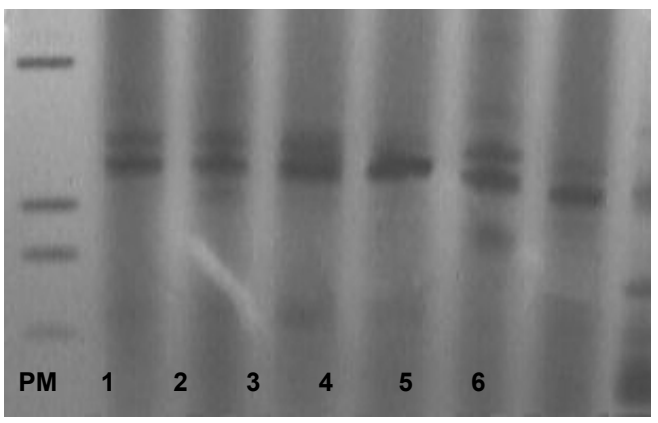

Figura 2. Eletroforese da amplificação com primer RM 29, primeira análise. DNA conservado em geladeira - padrão de peso molecular, com amostras dos touros (PM).
Este estudo permitiu a comparação de algumas técnicas de extração de DNA rotineiramente usadas em laboratórios, apontando as vantagens e desvantagens de cada uma delas quanto à quantidade e qualidade do extrato obtido. Ao final do estudo, pode-se concluir que, para um período de nove meses, não há diferença entre os métodos de conservação em freezer $\left(-20^{\circ} \mathrm{C}\right)$ ou em geladeira $\left(4^{\circ} \mathrm{C}\right)$. Também não foram observadas diferenças na quantidade de DNA e nível de contaminação protéica, sendo que o DNA extraído pelos métodos considerados rápidos mostrou-se eficiente para amplificações pela PCR durante os nove meses de estudos. A técnica permanente de extração de DNA para sangue foi a que forneceu maior quantidade de DNA com menor índice de contaminação. Para a extração de DNA de amostras de sêmen envasado conservado em gema de ovo, foram necessárias modificações nas técnicas originais, de modo a fornecer resultados satisfatórios.

Palavras-chave: DNA, métodos de extração, amplificação

\begin{abstract}
DNA samples of six bovines obtained from three tissues (blood, semen and hair) were extracted using two different techniques. After the extraction procedures the samples were divided in six fractions. Three were stored at $-20^{\circ} \mathrm{C}$ and three at $4{ }^{\circ} \mathrm{C}$. Every three months one sample of each tissuelextraction procedure was analyzed in spectrophotometer, to determine the quantity of the DNA and the extract was amplified using the primer RM 29. No differences in the DNA quantity or in the level of protein contamination among the three periods of analyses were observed. All the DNA extracted by quick extraction technique showed good amplification patterns during the nine months, meaning that this technique can be used in laboratory routine instead of the permanent extraction technique. The extract obtained from blood, using the permanent extraction technique, showed the higher quantity of DNA with the smaller index of protein contamination. The high quantity of protein contamination found in the semen samples preserved in egg yolk demanded modifications in both extraction techniques. After that the results were positive, showing good amplification patterns.
\end{abstract}

Keywords: DNA, extraction methods, amplification

\section{REFERÊNCIAS BIBLIOGRÁFICAS}

BARENDSE, W.; ARNUTAGE, S.M.; SHALOM, A. et al. A genetic linkage map of the bovine genome. Nature Gen.,v.6, p.227-234, 1994.
CATTANEO, C.; CRAIG, O.E.; JAMES, N.T. et. al. Comparison of three DNA extraction methods on bone and blood stains up to 43 years old and amplification of three different gene sequences. J. Forensic Sci., v.42, p.1126-1135, 1997. 
CRAIN, P.F. Preparation and enzymatic hydrolysis of DNA and RNA for mass spectrometry. Methods Enzymol., v.193, p.782790, 1990.

GALLAGHER, S.R..Quantitation of DNA and RNA with absorption and fluorescence spectroscopy. Current protocols in molecular biology. Suppl. 28 CPMB, appendix 3D, A.3D.1A.3D.8, 1994.

LEFF, L.G.; DANA, J.R.; McARTHUR, J.V. et al. Comparison of methods of DNA extraction from stream sediments. Appl. Envirom. Microbiol., v.61, p.1141-1143, 1995.

LEWIS, H.A.; STEWART-HAYNES, J. A simple method for DNA extraction from leucocytes for use in PCR. Biotechniques, v.13, p.522-523, 1992 .

MOORE, D. Preparation and analysis of DNA. Current protocols in molecular biology, Suppl. 24, 25 CPMB, c.2, 2.0.5 - 2.2.2, 1993.

SAMBROOK, J.; FRITSCH, E.F.; MANIATIS, T. Molecular cloning: a laboratory manual. New York: Cold Spring Harbor Laboratory Press, 1989. p.E.5-E.7.

SAMPAIO, I.B.M., Estatística aplicada à experimentação animal. Belo Horizonte: Fundação de Ensino e Pesquisa em Medicina Veterinária e Zootecnia, 1998. 221p. 